\title{
Raising intercultural awareness through short stories in EFL classes
}

\author{
Pınar Tural', Feryal Cubukcu•
}

\begin{abstract}
Teaching culture is an indispensable part of language teaching as language and culture are intertwined. Awareness of one's own culture and the target culture is necessary to be able to communicate efficiently. To raise intercultural awareness among EFL learners, literary sources can be a great source as they are authentic and reflect cultural elements. The aim of this study was to investigate the effect of short stories on intercultural awareness. In this quasi-experimental study, an experimental and a control group were chosen among $B 1$ level of EFL students. The research was carried out in the School of Foreign Languages at a university in the Western part of Turkey. In a six-week implementation period, the experimental group (18 students) read short stories with cultural themes from different cultures. On the other hand, the control group (19 students) read nonliterary texts again with cultural themes in them. In the study, quantitative data was collected through the Intercultural Awareness Questionnaire prepared by Zorba (2019), and the questionnaire was implemented as a pretest and posttest to gather data. The findings of the study showed that there was no meaningful change in the intercultural awareness of the study group before and after the implementation in terms of intercultural awareness. Furthermore, no significant difference was observed between the experimental and control groups. In the study, it was also concluded that gender and international experience did not lead to a difference in terms of intercultural awareness of participants. The overall conclusion that can be made from this study is that intercultural awareness focus in language teaching may ameliorate the language competence of learners, but it might take time to increase awareness among learners, so institutions should prioritize increasing awareness of EFL learners with various activities.
\end{abstract}

Keywords: Intercultural, language learning, short story.

\section{Introduction}

One of the defining words of the $21^{\text {st }}$ century is globalization. As Osterhammel and Petersson stress, "the world is becoming noticeably smaller as distant lands are being linked ever more closely together" (2005, p. 3). Today, distance and time problems have been eliminated; however, communication problems have occurred as communication has gained importance. There are two significant questions related to communication in this era. The first question is which language to speak. The answer is English because it

\footnotetext{
- Lecturer at Izmir Katip Celebi University, she got her B.A. and M.A. on Language Education. Currently she has been a doctoral student at Language Education. Her main interests are psycholinguistics and language teaching methods. Her mail address : toy.pinar@yahoo.com

- Full professor and head of the department of English Language Education at Dokuz Eylul University. Her main interests are psycholinguistics, teaching English, cultural studies, and critical theories. Her email address is cubukcu.feryal@gmail.com
} 
is the most spoken language in the world with 1.5 billion speakers including native and non-native speakers (Gordon \& Grimes, 2019). Furthermore, native speakers of English are politically, economically, and militarily powerful. English is the language of science, education, technology, media etc. The second question is how to communicate effectively and appropriately, especially in a non-native language. With this question, the meanings of language learning have changed and intercultural awareness in language teaching has gained momentum. To be able to use a language competently, it is necessary to have linguistic competence, knowledge of language. However, linguistic competence is not enough because to be competent in grammar and vocabulary does not mean that the language is used appropriately. In this respect, as Lee (1997) states, the main goal of foreign language learning is genuine interaction with people from different cultures, and so cultural competence is an indispensable part of foreign language learning. Also, Byram et al. argue that foreign language learning/teaching should include "intercultural competence i.e. ability to ensure a shared understanding by people of different social identities, and ability to interact with people as complex human beings with multiple identities and their own individuality" (2002, p. 10). In this globalized world, to be able to understand foreigners and to transmit our ideas clearly, intercultural awareness as one component of intercultural competence is necessary. Not having intercultural awareness may hamper effective communication. For this reason, while teaching English, a curriculum without an intercultural awareness focus might be tenuous. Therefore, culture is very important in foreign language teaching. Since English belongs to all individuals and communities who use the language, individuals who learn English as a foreign language must be aware of not only English and American cultures but also many different cultures. The aim of this study is to examine the effect of using short stories to raise intercultural awareness. It is expected that students will be able to read short stories that tell about different cultures, and it will contribute to their intercultural awareness.

\section{Language Competence}

A competence is "a bundle of cognitively controlled abilities or skills in some particular domain" (Lehmann, 2007, p. 224). Language competence has its own way from Chomsky's linguistic competence to communicative competence. For Chomsky, language competence is the knowledge of the language itself. It is the knowledge of phonetics, phonology, morphology, syntax, and semantics. Chomsky stresses the difference between competence and performance in Aspects of the Theory of Syntax:

Linguistic theory is concerned primarily with an ideal speaker-listener, in a completely homogeneous speech-community, who knows it's (the speech community's) language perfectly and is unaffected by such grammatically irrelevant conditions as memory limitations, distractions, shifts of attention and interest, and errors (random or characteristic) in applying his knowledge of the language in actual performance. (1965, p. 3) 
Chomsky was criticized with his narrow view of language learning as he did not give importance to communicative aspects of language. With Hymes, the concept of competence has been extended, and it included psycholinguistic perspectives. Hymes (1972) defined communicative competence with four dimensions, and he suggested that language learning requires the ability to use grammatical competence in a variety of communicative situations. These four dimensions are grammaticality, appropriateness, occurrence, and feasibility. Canale and Swain (1980) expanded communicative competence by including grammatical competence, sociolinguistic competence, discourse competence, and strategic competence into communicative competence. It has been understood that mastering the rules of language does not mean using the language; there are some other criteria. It is important to master the sociocultural and discourse rules. "The mastery of how to combine grammatical forms and meanings to achieve a unified spoken or written text in different genres" (Canale, 1983, p. 9) is necessary. Verbal and non-verbal communication strategies, which compensate for communication problems are an indispensable part of language learning.

\section{Intercultural Awareness}

The new perspectives in language teaching have stressed the necessity of culture teaching. With communicative approach, teaching target cultures has been integrated into language teaching as language and culture are bound to each other. Without an awareness of the target culture, it is difficult to communicate effectively in that target language. However, communicative approach which promotes the awareness of native cultures has been criticized because in this globalized world, English has been denationalized and the cultural content of ELT cannot be "reduced to a single, limited, monolingual or monocultural concept" (Nunn, 2005, p. 65). Kachru (1992) also agrees with this idea, and he gives numerous reasons for integrating other cultures to language teaching. Firstly, English is spoken by 1.5 billion people, and only 360 million are native speakers. The rest are non-native speakers. Secondly, English is "not an exponent of Western-Judeo-Christian tradition anymore" (Kachru, 1992, pp. 67-68). There are other institutionalized local models in the outer circles. Lastly, the English of expanding, and outer circles is interlanguage which strives to achieve native-like characteristics. Thus, it can be concluded that cultural competence is not enough under these conditions. What is a must is intercultural competence, and it is "the ability to communicate effectively and appropriately in intercultural situations based on one's intercultural knowledge, skills, and attitudes" (Deardorff, 2004, p. 194). Intercultural competence is a complex structure, and there are many models and components (Barrett, 2012; Byram et al., 2002; Fantini, 2000). "Intercultural awareness" is one of the two components of intercultural competence along with intercultural sensitivity and it can be defined as "a conscious understanding of the role of culturally based forms, practices and frames of understanding can have in intercultural communication, and an ability to put these 
conceptions into practice in a flexible and context specific manner in real time communication" (Baker, 2009, p. 88).

Intercultural awareness includes the cognitive perspectives of intercultural competence. Cognitive training includes "the change of thinking about the environment" (Triandis, 1977, p. 21), and intercultural awareness requires understanding and change in a person's ideas. Intercultural awareness has a significant role since it aims to prepare learners to cope with unexpected situations resulting from cultural differences (Rappel, 2011 , p. 4). If a person has an intercultural awareness, it can be easier for them to "reduce the level of ambiguity and uncertainty" (Chen \& Starosta, 1998, p. 30). Thus, it can be said that intercultural awareness is a requirement for communication, and as the main function of language learning is to be able to communicate, automatically; intercultural awareness becomes important in language teaching. The Council of Europe's Common European Framework of Reference (CEFR) also stresses the importance of intercultural awareness in language teaching: "it is a central objective of language education to promote the favorable development of the learner's whole personality and sense of identity in response to the enriching experience of otherness in language and culture" (2001, p. 1).

On the one hand, even if it is not aimed, it is inevitable to teach culture in language classrooms. Culture surrounds people. When people try to learn a language, whether they try to ignore it or not, they are exposed to culture. Zhou clearly expresses this:

Culture and communication are inseparable because culture not only dictates who talks to whom, about what, and how the communication proceeds, it also helps to determine how people encode messages, the meanings they have for messages, and the conditions and circumstances under which various messages may or may not be sent, noticed, or interpreted. Culture is the foundation of communication. (2011, p. 1)

Thus, while teaching English, intercultural awareness should be taken into account and several studies (Atay et al., 2009; Kawamura, 2011; Liu, 2016; Valdes, 1990; Yılmaz, 2016) also confirm that it should be integrated into language teaching.

\section{Use of Literature in Language Classroom}

A large number of educationalists (Brummfit, 1985; Duff \& Maley, Mckay, 1982; Van, 2009; Zyngier, 1994; 2007) put forward a number of reasons to include the use of literature in language classes. As authentic materials, they can be a great tool for personal involvement, language enrichment, and cultural/intercultural development, and several studies justify the effectiveness of literary texts in language teaching (Bahçe, 2008; Chen, 2013; Civelekoğlu, 2015). The use of short stories has also been investigated in several national and international studies (Andenoro et al., 2012; Baltes et al., 2014; Çandırlı, 2018; Derado, 2015; Logioio, 2010; Savic, 2012;). They all conclude that story telling is beneficial for enhancing intercultural awareness. 


\section{Methodology}

In this study, the effect of using short stories on the intercultural awareness levels of the participants in teaching English is investigated. The present study primarily attempts to seek answers to these questions:

1. Does using short stories in EFL classes have an impact on raising intercultural awareness?

2. Is there a difference between the experimental and control groups in terms of intercultural awareness posttest levels?

3. Does the gender have an effect on the intercultural awareness level of the experimental group?

4. Does the gender have an effect on the intercultural awareness level of the control group?

5. Does international experience have an effect on the intercultural awareness level of the experimental group?

6. Does international experience have an effect on the intercultural awareness level of the control group?

In the study, it is hypothesized that

1. Using short stories in EFL classes will have a positive impact on raising intercultural awareness.

2. The gender may have an effect on the intercultural awareness levels of the study group.

3. International experience may have a positive effect on the intercultural awareness levels of the study group.

\section{Research Design}

The aim of this study is mainly to examine the effect of using short stories to raise intercultural awareness of B1 level learners of English. To realize this aim, a quasiexperimental designed study was conducted at the School of Foreign Languages, at a university on the west side of the country. "Quasi-experimental designs do not include the use of random assignment" (Fraenkel et al., 2012, p. 275). At the School of Foreign Languages, classes are organized at the beginning of each semester, and they are assigned to instructors. For this reason, a quasi-experimental design was chosen in the study. The main idea behind all experimental studies is simple: "try something and systematically observe what happens" (Fraenkel et al., 2012, p. 262). The treatment is the use of short stories with intercultural themes, and its effect on intercultural awareness was measured through an intercultural awareness questionnaire. Also, the data were collected through quantitative research design. It can be defined as "explaining phenomena by collecting numerical data that are analyzed using mathematically based methods, in particular statistics" (Aliaga \& Gunderson, 2000, p. 5). Quantitative research design was preferred 
because it minimizes personal bias by eliminating subjectivity in judgment (Kealey \& Protheroe, 1996) and as Winter (2000) stresses, quantitative research design is valid and it can be replicable.

\section{Study Group}

The study was implemented at a university in the west part of the country in the School of Foreign Languages. The study group included 37 students. Before the implementation, consent forms were signed by the study group. The experimental group consisted of 18 students, and the control group consisted of 19 students. The study group was formed from already existing B1 classes. In the study, in choosing the experimental group, convenient sampling was used. The experimental group was the researcher's own class, and the control group has the closest medium to experimental group in terms of intercultural awareness. In this study, the participants were chosen among B1 students instead of A1 or A2 students because their English level is higher and as Ur (1996) states, literary texts might be demotivating for students whose English level is below intermediate.

\section{Data Collection Tools}

The Intercultural Awareness Questionnaire was administered before and after the intervention. The questionnaire was developed by Mehmet Galip Zorba (2019) and taken from his PhD Thesis called "Raising Intercultural Awareness of the $7^{\text {th }}$ Grade Students through Practical English Activities". The Cronbach's Alpha value of the questionnaire was .828 for the pretest and .806 for the posttest in his study. The validity of the questionnaire is based on expert opinion. In our study, The Cronbach's Alpha value was .912 as for the pretest and .855 as for the posttest.

\section{Data Collection Procedure}

Before the implementation, permissions from the ethics committee and related institution were obtained, and consent forms were signed by the study group. The pretest was administered to the experimental and control groups who volunteered in the first week. In the following six weeks, both of the groups read texts with cultural themes. As for the treatment, six short stories were incorporated into the study. The stories were The Relative Advantages of Relearning my Language by Amy Choi, Cat in the Rain by Earnest Hemingway, Eleven by Sandra Cisneros, Shame by Dick Gregory, The Beauty of Difference (Anonymous), and You Can't Choose Your Memories by Paul Nguyen. The difference between the groups was that the experimental group read short stories while the control group read nonliterary texts. While choosing the texts, the level of the texts, their readability, and length of the texts were taken into account. More importantly, what we understand from intercultural awareness is that variety in terms of themes and cultures are important to raise awareness. All the stories reflect a different theme in a different culture. While preparing the lesson plans, the main focus was on similarities and differences between the native and target cultures. It is believed that through input about 
different cultures and comparison, students' intercultural awareness might be developed. Lastly, in the eighth week, the posttest was given to the groups to see if their intercultural awareness levels differed.

\section{Research ethics}

Dokuz Eylül University Research Ethics Committee approved the study on 27 Dec. 2019 (Document number is 16). Also, participants were informed about the details of the study. The participation was on a voluntary basis. Lastly, permission for using the instrument was obtained via e-mail.

\section{Data analysis}

For data analysis, SPSS 23 (Statistical Package for the Social Sciences) Software program was used. The means of different groups were assessed through an independent samples t-test. For comparing means from the same group at different times, a paired sample ttest was preferred. When analyzing the data, $\mathrm{p}<.05$ was used as significance level.

\section{Findings and Discussion}

The aim of the study was to reveal whether using short stories could affect intercultural awareness levels of learners or not. In an attempt to investigate the relationship between using short stories and intercultural awareness, the participants' intercultural awareness levels were measured through Intercultural Awareness Questionnaire (Zorba, 2019). The pretest was administered to the experimental and control groups. After the pretests, the experimental group read short stories which included intercultural themes, and the control group read nonliterary texts with intercultural themes. After a six-week implementation, the posttest was given to both of the groups to find out if using short stories promoted the intercultural awareness levels of participants. The results obtained from this research are discussed below regarding the research questions and related studies in the field.

\section{Does using short stories in EFL classes have an impact on raising intercultural awareness?}

Table 1. Paired samples $t$-test results of the pretest and posttest of the experimental group

\begin{tabular}{ccccc}
\hline & Number & Mean & Std. Deviation & Sig. (2-Tailed) \\
\hline Pretest results & 18 & 3.98 & .29 & .13 \\
Posttest results & 18 & 4.09 & .39 & \\
\hline
\end{tabular}

Although there is an increase in the levels of intercultural awareness of the participants by using short stories, the increase is not statistically significant $(\mathrm{p}=.13>$ .05). The pretest and posttest results of the research clearly showed that using short stories did not help the students to raise intercultural awareness because there was not a statistically significant difference between the pretest and posttest results of the experimental group $(\mathrm{p}=.13>.05)$. One similar study was conducted by Aşni and Çelik (2015). 
They also used the story Cat in the Rain, and in this qualitative study, they concluded that the story was not adequate to raise intercultural awareness among participants. One reason why short stories were not effective in raising intercultural awareness might be that participants in our study and in the study of Aşni et al. might not have been interested in reading literary texts. in a limited amount of time. In addition to this study, there are quantitative studies (Civelekoğlu, 2015; Risner, 2011; Zorba \& Çakır, 2019) with similar results. Moreover, there are other studies (Abida \& Kuswardani, 2017; Civelekoğlu 2015; Moecharam \& KartikaSari, 2014; Nie, 2017) which investigated the effects of literary texts on raising intercultural awareness. It might be suggested that it is difficult to change intercultural awareness of participants as Korzilius et al. (2007) suggested. Another study which supported this idea is an experimental study conducted by Risner (2011), and she found out that it was difficult to change the awareness levels of participants in a limited period of time.

On the other hand, there are many studies which claim that using short stories is beneficial to promoting intercultural competence (Burwitz-Melzer, 2001; Çandırlı, 2018; Derado, 2015; Zapata, 2005; Logioio, 2010; Andenoro et al., 2012; Moecharam \& KartikaSari, 2014; Savic, 2012; Stevens 2014; Rezaei \& Naghibian, 2018). In another study, Rodríguez (2012) showed that EFL learners could build cultural knowledge through literary materials and favored authentic materials to raise intercultural awareness. The study showed different results from our study. The reasons for this might be the differences in study group, duration of the study, method the researcher used, and the extra project the study group worked on. Her study group was university pre-service EFL teachers and their competency both in English and intercultural competence might be different from our study group who were preparatory school students. Furthermore, the implementation took more time than our study did. In addition to these, she used various approaches while presenting the short stories: inquiry-based approach, dialogic approach, transactional approach, and content based approach. One last difference was that the participants had worked on class projects to study cultural content of the U.S., the United Kingdom, Australia and Canada. For these reasons, the results of this study and our study might have differed.

Finally, when our study was compared with the studies where the components of intercultural competence increased, one last reason why intercultural awareness of our study group was not improved could be due to the effects of the coronavirus pandemic the world was undergoing. In some of the weeks of the implementation, people all around the world including our participants were afraid of the virus, and people distanced from each other physically. It might have led to a psychological distance as well, and our participants' feelings, thoughts, and tolerance might have been affected negatively, so it might have influenced posttest results. 
Is there a difference between the experimental and control groups in terms of intercultural awareness posttest levels?

Table 2. Independent samples $t$-test results of the posttests of the experimental and control groups

\begin{tabular}{ccccc}
\hline & Number & Mean & Std. Deviation & $\begin{array}{c}\text { Sig. (2- } \\
\text { Tailed) }\end{array}$ \\
\hline $\begin{array}{c}\text { Experimental } \\
\text { group }\end{array}$ & 18 & 4.09 & .39 & .90 \\
Control group & 19 & 4.10 & .31 & \\
\hline
\end{tabular}

It could be said that two groups are alike in terms of posttest intercultural awareness levels $(p=.90>.05)$. It could be said that the experimental and control groups resembled each other in terms of intercultural awareness posttest levels $(p=.90>.05)$. If the studies related to intercultural issues are reviewed, it can be concluded that in some studies there were control groups with different kinds of treatments, and in other studies control group was not exposed to any extra activities with intercultural themes. It is important to differentiate between them because when there is exposure to intercultural themes; it might lead to different results. In the present study, the experimental group studied literary texts. On the other hand, the control group studied nonliterary texts. In a similar vein, Bérešová (2014) conducted research on cultural awareness by comparing literary and nonliterary texts, and the researcher claimed that because there was a slight difference between the two groups, any texts with cultural themes, could enhance intercultural awareness. Besides, there are some other studies (Güneş, 2016; Korziliuz et al., 2007; Topaloğlu, 2016; Zorba \& Çakır, 2019) where the experimental and control groups did not differ after the implementation.

On the other hand, there are studies (Bahçe, 2008; Çandırlı, 2018; Derado, 2015; Scott \& Huntington, 2008; Zacharias, 2005) where experimental and control groups differed because of the choice of literary and nonliterary texts. Basically, in these studies, using literary texts worked better.

\section{Does the gender have an effect on intercultural awareness?}

Table 3. Posttest scores of the experimental group by gender

\begin{tabular}{ccccc}
\hline Gender & Number & Mean & Std. Deviation & $\begin{array}{c}\text { Sig. (2- } \\
\text { Tailed) }\end{array}$ \\
\hline Female & 6 & & .22 & .18 \\
Male & 12 & 4 & .43 & \\
\hline
\end{tabular}

In Table 3, it appears that although females $(M=4.26)$ have a higher level of intercultural awareness level than males $(M=4)$, there is no difference between the female and male participants in the experimental group ( $p=.18>.05)$.

In the experimental and control groups, the difference between the pretests and posttests was not significant $(\mathrm{p}=.18>.05$ and $\mathrm{p}=.93>.05)$. In the literature, there are various studies which investigated how intercultural competence and its components are 
related to various demographic factors (e.g. age, gender, level of education, etc.), and there are a number of studies (Altan, 2018; Baltes et al., 2015; Günçavdı \& Polat, 2016; Hammer et al., 2003; Lei, 2016; Oksoon et al., 2017) with similar results to our study.

On the other hand, there are some other studies at which the researchers found out that gender had an effect on intercultural competence or its components. Topaloğlu (2016) focused on gender and intercultural awareness and he stated that both pretest and posttest results specified that the variable of gender caused a significant difference. It was observed that intercultural sensitivity of male participants increased more than that of females. Soltani and Rahimi (2016) also indicated that the mean difference between intercultural sensitivity of the males and females was statistically significant, and males performed better than females. While these two studies showed that males were better, other studies (Holm et al., 2009; Tompkins et al., 2017; Solhaug \& Kristensen, 2019) suggested that females were better. However, in our study, gender was not an influential factor in intercultural awareness.

\section{Does international experience have an effect on intercultural awareness?}

Table 4. Posttest scores of the experimental group by international experience

\begin{tabular}{clllc}
\hline $\begin{array}{l}\text { International } \\
\text { Experience }\end{array}$ & Number & Mean & Std. Deviation & $\begin{array}{c}\text { Sig. } \\
\text { Tailed) }\end{array}$ \\
\hline Yes & 6 & 4.15 & .33 & .64 \\
No & 12 & 4.06 & .42 & \\
\hline
\end{tabular}

International experience slightly affected intercultural awareness levels of the experimental group, but the significance is not meaningful $(p=.64>.05)$ in the experimental group.

Table 5. Posttest scores of the control group by international experience

\begin{tabular}{|c|c|c|c|c|}
\hline $\begin{array}{l}\text { International } \\
\text { Experience }\end{array}$ & Number & Mean & Std. Deviation & $\begin{array}{l}\text { Sig. } \\
\text { Tailed) }\end{array}$ \\
\hline Yes & 5 & 4.03 & .22 & .54 \\
\hline No & 14 & 4.13 & .33 & \\
\hline
\end{tabular}

International experience slightly affected intercultural awareness levels of the experimental group, but the significance is not meaningful ( $p=.64>.05$ ). Also, the results of the control group showed that there is not a statistically significant difference between the pretest and posttest results $(p=.54>.05)$. From these statistics, it was concluded that international experience did not affect intercultural awareness of both the experimental and control groups. Similarly, Yurtseven and Altun (2015) carried out a study among preservice English teachers to learn if there was a relationship between intercultural sensitivity levels of participants and the state of going abroad and concluded that the relationship was not significant. Another comparable study was conducted by Çandırlı (2018). Furthermore, there are various international studies (Fabregas et al., 2012; 
Mcmurray, 2007; Richard \& Doorenbos, 2016; Safipour et al., 2017) which studied and found no relationship between international experience and the components of intercultural competence.

On the other hand, there are many other studies (Balkaya, 2017; Bosuwon, 2016; Boštjančič \& Johnson, 2019; Gage, 2001; Jurgens \& McAuliffe, 2004; Karras, 2017; Penbek, Yurdakul, \& Cerit, 2012) which coincided with our study. They concluded that international experience and various components of intercultural competence were related and international experience increased intercultural competence. However, in our study, international experience did not affect intercultural awareness of the participants.

\section{Conclusion}

This study examined whether using short stories could promote intercultural awareness of EFL students. Also, the effects of gender and international experience on intercultural awareness were investigated. For these purposes, two groups of B1 level EFL students took part in a six-week experiment in the spring term of 2019-2020. The study was conducted in the School of Foreign Languages in the west part of the country. Before the treatment, Intercultural Awareness Questionnaire (Zorba, 2019) was used as a pretest, and it was administered to the experimental and control groups. One group (experimental) read six short stories whereas the other group read six nonliterary texts. Both types of the texts included intercultural themes for different cultures in them. After a six-week implementation, the same questionnaire prepared by Zorba (2019) was given to both groups. The results which were reached by using the independent samples t-tests and the paired sample t-tests showed that:

1. Short stories did not raise intercultural awareness of the study group.

2. Using literary texts and nonliterary texts did not make a difference in terms of intercultural awareness.

3. Intercultural awareness of the participants was not affected by gender.

4. Intercultural awareness of the participants was not affected by international experience.

Finally, it should be noted that intercultural awareness should be integrated into language teaching. Curriculum developers, policy makers, and other stakeholders should equally prioritize increasing intercultural awareness. Also, language learners may benefit from different materials including literary and nonliterary texts to raise intercultural awareness. Lastly, it might be necessary to have a long term plan as changing awareness of students is not easy in short time.

\section{Acknowledgments}

This article has been adapted from a dissertation. 


\section{References}

Abida F. I. N., \& Kuswardani, R. (2017). Developing intercultural awareness through poems in EFL classrooms. Advances in Social Science, Education and Humanities Research, 108, 235-239.

Aliaga, M., \& Gunderson, B. (2000). Interactive statistics. Prentice Hall.

Altan, M. Z. (2018). Intercultural sensitivity a study of pre-service English language teachers. Journal of Intercultural Communication, 46, 1-17.

Andenoro, A., Popa, A., Bletscher, C., \& Albert, J. (2012). Storytelling as a vehicle for self- awareness: Establishing a foundation for intercultural competency development. Journal of Leadership Studies. 6(2), 102-109.

Aşni D., \& Çelik, A. (2015). Raising cultural awareness through literature (Graduation Project). Retrieved on March 6, 2020 from https://www.academia.edu/10451347/Raising_Cultural_Awareness_Through_Literature

Atay, D., Kurt, G., Çamlıbel, Z., Ersin, P., \& Kaslıoğlu, Ö. (2009). The role of intercultural competence in foreign language teaching. Inönü University Journal of the Faculty of Education, 10(3), 123-135.

Bahçe, N. (2008). The effects of epics on intercultural awareness (Unpublished Master's Thesis). Selçuk University Institute of Social Sciences: Konya (No. 218705).

Baker, W. (2009). Intercultural awareness and intercultural communication through English: An investigation of Thai English language users in higher education (Unpublished Doctoral Thesis). University of Southampton School of Humanities: Southampton. Retrieved on September 5, 2019 from http://eprints.soton.ac.uk/id/eprint/66542

Balkaya, Ş. (2017). Lise öğrencilerinin Almanlara ve Almancaya karşı tutum, önyargı ve kalıp yargıları (Unpublished Master's Thesis). Muğla Sitkı Koçman University Institute of Educational Sciences: Muğla (No: 483103).

Baltes, B, Hernandez, D., \& Collins, C. (2015). Increasing cultural awareness through a cultural awareness program. Journal of Educational Research and Practice, 5(1), 1-20.

Baltes, B., Maldonado, N., \& McCullum, M. (2014). Storytelling to teach cultural awareness: The right story at the right time. Learning Landscape, 7(2), 219-232.

Barrett, M. (2012). Intercultural competence. EWC Statement Series, $2^{\text {nd }}$ Issue (p. 23-27). Norway: European Wergeland Centre. Retrieved on June 18, 2021 from https://theewc.org/content/uploads/2020/02/EWC-Statement-Series-2012.pdf

Bérešová, J. (2014). Literary texts as a source of cultural awareness and language acquisition. Journal of International Scientific Publications, 8, 167-174.

Boštjančič, E., \& Johnson, R. B. (2019). The role of students' experiences living abroad and demographic factors on development of cultural intelligence. Anthropos, 1(2), 9-25.

Bosuwon, T. (2016). A study of international undergraduates' intercultural sensitivity levels and their predictors. Retrieved on April 3, 2020 from http://department.utcc.ac.th/library/onlinethesis/263327.pdf

Brumfit, C. (1985). Language and literature teaching: From practice to principle. Pergamon Press.

Burwitz-Melzer, E. (2001). Teaching intercultural communicative competence through literature. In M. Byram, A. Nicholas, \& D. Stevens (Eds.), Developing intercultural competence in practice (pp. 29-43). Multilingual Matters.

Byram, M., Gribkova, B. \& Starkey, H. (2002). Developing the intercultural dimension in language teaching. A practical introduction for teachers. Strasbourg: Council of Europe.

Canale, M. (1983). From communicative competence to communicative language pedagogy. In J. C. Richards, \& W. Schmidt, (Eds.) Language and communication. Routledge.

Canale, M., \& Swain, M. (1980). Theoretical bases of communicative approaches to second language teaching and testing. Applied Linguistics, 1, 1-47. 
Chen, I. W. (2013). Efl learners developing critical intercultural awareness through process drama:Dialogue and discovery (Unpublished Doctoral Thesis). Retrieved on March 2, 2020 from http://etheses.dur.ac.uk/8464/

Chen, G., \& Starosta, W. J. (1998). Foundations of Intercultural Communication. Mass.: Allyn \& Bacon.

Chomsky, N. (1965). Aspects of the theory of syntax. Cambridge: The MIT Press.

Civelekoğlu, N. (2015). The use of poetry to raise intercultural awareness of Efl students (Unpublished Master's Thesis). Akdeniz Unıversity Institute of Educational Sciences: Antalya (No. 394928)

Council of Europe. (2001). Common European framework of reference for languages:Learning, teaching, assessment. Cambridge: Press Syndicate of the University of Cambridge. Retrieved on September 15, 2009 from https://rm.coe.int/16802fc1bf

Çandırlı, B. (2018). A study on intercultural competence of pre-service Efl teachers through short stories (Unpublished Master's Thesis). Muğla Sitkı Koçman University Institute of Educational Sciences: Muğla (No. 530603).

Deardorff, D.K. (2004). The identification and assessment of intercultural competence as a student outcome of international education at institutions of higher education in the United States. Language and Literature: International Journal of Stylistics, 10(3), 241-265.

Derado, S. R. (2015). Fostering cross-cultural communicative competence in business English classes through literary short stories. Journal of English for Specific Purposes at Tertiary Level, 3(1), 99-119.

Duff, A., \& Maley, A. (2007). Literature. Oxford University Press.

Fabregas, J. M. G., Kelsey, K. D., \& Robinson, S.J. (2011). Predicting intercultural sensitivity using demographic variables among college of agriculture undergraduate students. US-China Education Review, 8, 710-719.

Fantini, A. E. (2000). A central concern: Developing intercultural competence. SIT Occasional Papers Series: Addressing Intercultural Education, Training and Service, 1, 25-42.

Fraenkel, J. R., Wallen, N. E., \& Hyun H. H. (2012). How to design and evaluate research in education ( $8^{\text {th }}$ Ed). McGraw-Hill.

Gage, M. (2001). International study for outstanding students: A case study. New Directions for teaching and learning, 85, 43-48.

Gordon, R. G., \& Grimes, B. F. (2019). Ethnologue: Languages of the world. SIL.

Günçavdı, G., \& Polat, S. (2016). Level of intercultural competence of international students at Kocaeli University, Universal Journal of Educational Research 4(12A), 39-45.

Güneș, S. (2016). The effect of using Elf materials on the development of intercultural awareness and the attitudes of language learners (Unpublished Master's Thesis). Erciyes University Institute of Social Sciences: Kayseri (No: 429228).

Hammer, M. A., Bennett, M. J., \& Wiseman, R. (2003). Measuring intercultural sensitivity: The intercultural development inventory. International Journal of Intercultural Relations, 27, 421- 443

Holm, K., Nokelainen, P., \& Tirri, K. (2009) Relationship of gender and academic achievement to Finnish students' intercultural sensitivity. High Ability Studies, 20(2), 187-200.

Hymes, D.H. (1972). On communicative competence. In J.B. Pride, \& J. Holmes (Eds. Sociolinguistics (p. 269293). Penguin Books Ltd

Jurgens, J. C., \& McAuliffe, G. (2004). Short-term study-abroad experience in Ireland: An exercise in crosscultural counseling. International Journal for the Advancement of Counselling, 26, 147-161.

Kachru, B. B. (1992). Models for nonnative Englishes. In B.B. Kachru, (Ed.), The other tongue: English across cultures (2 $2^{\text {nd }}$ Edition), (p. 48-74). University of Illinois

Karras, I. (2017).The effectiveness of an intercultural communication course in increasing international and european studies students' intercultural sensitivity. Intercultural Communication Studies, 26(2), 96-118. 
Kawamura, M. (2011). A study of native English teachers' perception of English teaching: Exploring intercultural awareness vs. practice in teaching English as a foreign language (Unpublished Doctoral Thesis). Retrieved from ProQuest Dissertations and Theses database. (UMI No.3489218).

Kealey, D.J., \& Protheroe, D.R. (1996). The effectiveness of cross-cultural training for expatriates: An assessment of the literature on the issue. International Journal of Intercultural Relations, 20(2), p. 141165.

Korzilius, H., Hooft, A., \& Planken, B. (2007). A Longitudinal study on intercultural awareness and foreign language acquisition in the Netherlands. Journal of Intercultural Communication, 15, 76-105.

Lee, L. (1997). Using internet tools as an enhancement of $\mathrm{C} 2$ teaching and learning. Foreign Language Annals, 30(3), 410-427.

Lei, W. (2016). The impact of international online debate on intercultural sensitivity, intercultural awareness, and perception of sustainability (Unpublished Master's Thesis). Retrieved on 4 March, 2020 from https://digitalcommons.uri.edu/theses/885

Lehmann, C. (2007). Linguistic competence: theory and empiry. Folia Linguistica, 42, 223 -278.

Liu, C. (2016). Cultivation of intercultural awareness in Efl teaching. Journal of Language Teaching and Research, 7(1), 226-232.

Logioio, A. J. (2010). Raising intercultural awareness at primary level through storytelling within a Clil approach (Unpublished Master's Thesis). Retrieved on March 8, 2020 from http://citeseerx.ist.psu.edu/viewdoc/download?

McKay, S. (1982). Literature in ESL classroom. TESOL Quarterly, 16(4), 529-536.

Mcmurray, A. A. (2007). Measuring intercultural sensitivity of international and domestic college students: The impact of international travel (Unpublished Master's Thesis). Retrieved on March 9, 2020 from https://ufdcimages.uflib.ufl.edu/UF/E0/02/12/39/00001/mcmurray a.pdf

Moecharam, N. Y., \& Kartika Sari A. (2014). Let's talk and tolerate: Strengthening students cultural awareness through literature circles. Indonesian Journal of Applied Linguistics, 3(2), 117-12.

Nie, Y. (2017). Facilitating intercultural study through novel reading. Theory and Practice in Language Studies, 7(6), 436-442.

Nunn, R. (2005). Competence and teaching English as an international language. Asian EFL Journal, 7(3), 61-74.

Oksoon, K. Dancel, M., Dancel, R., Baniasen, J., Carr, A., Doyle, S., Laishramcha, J., \& McLaughlin, R. (2017). The intercultural sensitivity of Korean University students for the development of programs promoting intercultural sensitivity. Forum for Youth Culture, 51, 7-39.

Osterhammel, J., \& Petersson, N. P. (2005). Globalization: A short history. Princeton University Press.

Penbek, Ş., Yurdakul, D., \& Cerit, G. (2012). Intercultural communication competence: A study about the intercultural sensitivity of university students based on their education and international experiences. International Journal of Logistics Systems and Management, 11(2), 232-252.

Rappel, L. (2011). An analysis and interpretation of intercultural approaches to English language teaching. Journal of Integrated Studies, 1, 1-7.

Rezaei, S., \& Naghibian, M. (2018). Developing intercultural communicative competence through short stories: A qualitative inquiry. Iranian Journal of Language Teaching Research, 6(2), 77-96.

Richards, C. A., \& Doorenbos, A. Z. (2016). Intercultural competency development of health professions students during study abroad in India. Journal of Nursing Education and Practice, 6(12), 89-98.

Risner, M. E. (2011). Developing intercultural competence through blended learning: the role of peer interaction (Unpublished Doctoral Thesis). Retrieved from ProQuest Dissertations and Theses database. (UMI No. 3514907).

Rodriguez, L. F. G. (2012). The inclusion of multicultural literary texts from the U.S. with the teaching of English as a foreign language: A pedagogical convergence to foster EFL learner's intercultural competence (Unpublished Doctoral Thesis). Retrieved from ProQuest Dissertations and Theses database. (UMI No. 3538804). 
Safipour, J., Hadziabdic, E., Hultsjö, S., \& Bachrach-Lindström, M. (2017). Measuring nursing students' cultural awareness: A cross-sectional study among three universities in southern Sweden. Journal of Nursing Education and Practice, 7(1), 107-113.

Savic, V. (2012). Developing intercultural literacy in the young learner classroom, presented at Integrating Culture and Language Teaching in TEYL. City Press.

Scott, V. M, \& Huntington J. A. (2008)._Reading culture: Using literature to develop C2 competence. Foreign Language Annals, 35(6), 622-631.

Solhaug, T., \& Kristensen, N. N. (2019): Gender and intercultural competence: Analysis of intercultural competence among upper secondary school students in Denmark and Norway. An International Journal of Experimental Educational Psychology. Retrieved on March 20, 2020 from https://doi.org/10.1080/01443410.2019.1646410

Soltani, A., \& Rahimi, A. (2016). The interface between Iranian Efl teachers' intercultural sensitivity and their ethnic and demographic backgrounds. Global Journal of Language Teaching, 6(1), 36-45.

Stevens, A. E. P. (2014). Short stories as a source of cultural insight when teaching English (Master's Thesis). Retrieved on June 18, 2021 from https://core.ac.uk/download/pdf/52117558.pdf

Tompkins, A., Cook, T., Miller, E., \& LePeau, L. A. (2017). Gender influences on students' study abroad participation and intercultural competence. Journal of Student Affairs Research and Practice, 54(2), 204-216.

Topaloğlu, O. (2016). Raising critical intercultural awareness through creative drama in higher education Efl classes (Unpublished Doctoral Thesis). Atatürk University Institute of Educational Sciences: Erzurum (No: 433828).

Triandis, H. C. (1977). Theoretical framework for evaluation of cross-cultural training. International Journal of Intercultural Relations, 1(4), 19-45

Ur, P. (1996). A course in language teaching: practice and theory. Cambridge University Press

Valdes, J. (1990). The inevitability of teaching and learning culture in a foreign language e course. In B. Harrison, (Ed.), Culture and the language classroom (p. 20-30). UK: Modern English Publication

Van Ek, J. 1986. Objectives for foreign language learning. Council of Europe.

Yilmaz, A. (2012). The impact of the integration of short stories and the computer-assisted language learning on the motivation level of students (Unpublished Master's Thesis). Çanakkale Onsekiz Mart University Institute of Educational Sciences: Çanakkale (No.345865).

Yurtseven, N., \& Altun, S. (2015). Intercultural sensitivity in today's global classes: Pre-service teachers' perceptions. Journal of Ethnic and Cultural Studies, 2(1), 49-54.

Winter, G. (2000). A comparative discussion of the notion of 'validity' in qualitative and quantitative research. The Qualitative Report, 4(3), 1-14.

Zacharias, N. T. (2015). Developing intercultural competence through literature. CELT, 5(1), 27-41.

Zapata, G. C. (2005). Literature in L2 Spanish classes: An examination of focus-on-cultural understanding. Language awareness, 14(4), 261-273.

Zhou, Y. (2011). A study of chinese university Efl teachers and their intercultural competence teaching (Unpublished Doctoral Thesis). Retrieved on March 1, 2020 from https://scholar.uwindsor.ca/etd/428/

Zorba, A. G. (2019). Raising intercultural awareness of the 7th grade students through practical English activities (Unpublished Doctoral Thesis). Gazi University Institute of Educational Sciences (No: 543808).

Zorba, A. G., \& Çakır, A. (2019). A case study on intercultural awareness of lower secondary school students in Turkey. Novitas-ROYAL, 13(1), 62-83.

Zyngier, S. (1994). A theory of the literary text. Language and Literature: International Journal of Stylistics, $3(1), 71-74$. 